RAPHISA.

Revista de Antropología y Filosofía de lo Sagrado

Review of Anthropology and Philosophy of the Sacrum

ISSN: 2530-1233 Nº 4, Julio-Diciembre (2018) pp.: 25-34

\title{
THE BACCHANTIC FEAST AS A DUALISM
}

\section{LA FIESTA BACANTE COMO DUALISMO}

\author{
Simona Chiodo ${ }^{1}$ \\ Politecnico di Milano (Italia)
}

\begin{abstract}
The bacchantic feast, especially as it is described in Euripides's Bacchae, is a powerful example of what may be thought of as the most essential cornerstone of Western culture: the dualism between the dimension of reality (represented by Pentheus) and the dimension of ideality (represented by the bacchantic feast). In particular, why must the former die after having seen the latter? That is, why the dimension of ideality (as well as the dimension of the sacred) can be essential, and even a saviour, for the dimension of reality (as well as for the dimension of the profane) if and only if the dualism between them is rigorously respected? I shall try to answer this question, and to use my answer as a clue to start investigating another essential structure of the dualism between reality and ideality which founds Western culture, by passing from its religious meaning to its epistemological meaning.
\end{abstract}

\section{Key words: DUALISM; IDEALITY; EURIPIDES}

Resumen: La fiesta bacante, especialmente como se describe en el Bacchae de Eurípides, es un poderoso ejemplo de lo que puede considerarse como la piedra angular más esencial de la cultura occidental: el dualismo entre la dimensión de la realidad (representada por Pentheus) y la dimensión de la idealidad ( representado por la fiesta bacchantic). En particular, ¿por qué debe morir el primero después de haber visto el segundo? Es decir, por qué la dimensión de la idealidad (así como la dimensión de lo sagrado) puede ser esencial, e incluso un salvador, para la dimensión de la realidad (así como para la dimensión de lo profano) si y solo si el dualismo entre ¿Se los respeta rigurosamente? Intentaré responder a esta pregunta y utilizar mi respuesta como una pista para comenzar a investigar otra estructura esencial del dualismo entre realidad e idealidad que fundamenta la cultura occidental, pasando de su significado religioso a su significado epistemológico.

Palabras clave: DUALISMO; IDEALIDAD; EURIPIDES

[1] (simona.chiodo@polimi.it) es profesora titular en el Politecnico di Milano, impartiendo "Epistemología" "Fundamentos de la estética" y "Estética de la arquitectura" y coordinando el curso internacional interdoctoral "Epistemología de la ciencia e investigación tecnológica Guido Nardi”(desde el 8 de enero de 2018). 
When Pentheus asks Dionysus «How is thy worship held, by night or day?»" Dionysus answers "Most oft by night; 'tis a majestic thing, / the darkness ${ }^{3}$. But Pentheus chooses to ignore Dionysus's caveat, and violates the sacredness of the bacchantic feast. Thus, he is put to death. The messenger reports:

Then, "Hither", cried Agâvê; "stand we round and grip the stem, my Wild Ones, till we take this climbing cat-o'-the-mount! He shall not make a tale of God's high dances!". Out then shone arm upon arm, past count, and closed upon the pine, and gripped; and the ground gave, and down it reeled. And that high sitter from the crown of the green pine-top, with a shrieking cry fell, as his mind grew clear, and there hard by was horror visible. 'Twas his mother stood o'er him, first priestess of those rites of blood. He tore the coif, and from his head away flung it, that she might know him, and not slay to her own misery. He touched the wild cheek, crying: "Mother, it is I, thy child, thy Pentheus, born thee in Echîon's hall! Have mercy, Mother! Let it not befall through sin of mine, that thou shouldst slay thy son!". But she, with lips a-foam and eyes that run like leaping fire, with thoughts that ne'er should be on earth, possessed by Bacchios utterly, stays not nor hears. Round his left arm she put both hands, set hard against his side her foot, drew... and the shoulder severed! Not by might of arm, but easily, as the God made light her hand's essay. And at the other side was Ino rending; and the torn flesh cried, and on Autonoë pressed, and all the crowd of ravening arms. Yea, all the air was loud with groans that faded into sobbing breath, dim shrieks, and joy, and triumph-cries of death. And here was borne a severed arm, and there a hunter's booted foot; white bones lay bare with rending; and swift hands ensanguined tossed as in sport the flesh of Pentheus dead. His body lies afar. The precipice hath part, and parts in many an interstice lurk of the tangled woodland - no light quest to find. ${ }^{4}$

[2] Euripides, The Bacchae, tr. by G. Murray, London: Allen, 1906, p. 30.

[3] Ibid.

[4] Ibid., pp. 65-66. 
Pentheus's death helps focus on other important elements of the structure of the sacred. The first element has to do with the affirmation of its existence (Dionysus affirms, and does not deny, the existence of the bacchantic feast), of its difference from the ordinary existence (Dionysus makes reference to the opposition between night and day, darkness and light) and of its inviolability. The sacred is explicit, and not implicit - we may say that the sacred is an epistemological, and not ontological, mystery, since the question we cannot answer is "What happens beyond the limit which divides the sacred from the profane?", and not "Does the sacred exist?". The existence of the sacred, together with its difference from the ordinary existence and inviolability, is given a priori: it is clearly affirmed, it is not a mystery and, moreover, it must not be a mystery. On the contrary, what happens beyond the limit which divides the sacred from the profane is not given at all: it is not given a priori, it is not given a posterio$r i$, it is not affirmed, it is an irreducible mystery and, moreover, it must be an irreducible mystery. Why? That is, why do two opposite conditions (the affirmation of the existence of the sacred, on the one hand, and the affirmation of its irreducible difference and inviolability, on the other hand) are consistent? If the existence of a radical otherness, which is the sacred, is affirmed to be essential and necessary, why does the ban of a direct relationship with the sacred is affirmed to be equally essential and necessary? That is, why does a thing bring salvation and death at the same time?

Let us add the second element: Pentheus's violent death should not deviate us from its actual cause, which is not a matter of punishment, but a matter of guarantee of a precise objective, which is preventing the divulgation of what happens in the bacchantic feast. Knowing what happens beyond the limit which divides the sacred from the profane is banned since its dangerousness has to do with a universal, and not a particular, dimension. That is, the reason why Pentheus is reduced to pieces is that what is crucial is not that a particular human being must not know what happens beyond the limit which divides the sacred from the profane - on the contrary, what is crucial is that the society, that is, the entire humankind, must not know what there is in the sacred: the violation of the sacred by a particular human being is banned, but the divulgation of what there is in the sacred to the entire humankind is even more banned, since divulgating the content of the sacred is dangerous for the conditions to which the existence of the humankind is possible. Pentheus has a direct relationship with the content of the sacred and consequently dies being reduced to pieces because of something that has to do with the relationship between the other human beings and the sacred more than with the relationship between himself and the sacred. If the actual reason of Pentheus's death 
is the necessity of punishing the violator, then his being reduced to pieces and, moreover, the prevention of the divulgation of what happens in the bacchantic feast are superfluous. But the essentiality of both his being reduced to pieces and the prevention of the divulgation of what happens in the bacchantic feast seems to indicate that the actual reason of Pentheus's death is the necessity of dividing the violator from the society he takes part in, that is, of extinguishing that part of the humankind which has a direct relationship with the content of the sacred with the precise objective of preventing the possibility of its divulgation.

Thus, the question changes: the general question "Why does a thing bring salvation and death at the same time?" is to be specified by the particular question "Why does the sacred bring the entire humankind salvation and death at the same time?" - and "What epistemology does this almost paradoxical mechanism make reference to?".

The death (and the ban) of the one who overcomes the limit which divides the sacred from the profane, that is, of the one who embodies the possibility of their fusion, is the condition of the existence of both the profane, which is the entire humankind (and the reality as well), and the sacred (and the ideality as well), since it seems that the two dimensions can exist if they are two quasi-absolute dimensions, that is, two elements whose relationship is founded on the denial of the possibility of their fusion. It seems that the sacred and the profane can, and must, be contiguous, but not continuous - it seems that the sacred and the profane can, and must, be two quasi-absolute dimensions which have a dualistic relationship, since they affirm the necessity of their relationship, but cannot, and must not, pass from an antithesis (that is, from the affirmation of their radical difference) to a synthesis (that is, to the affirmation of the overcoming of their radical difference through their fusion).

The meaning of the death (and of the ban) seems to clarify the epistemological mechanism which the dualistic relationship between the sacred and the profane seems to entail. The epistemological mechanism seems the following:

1. it is necessary to pass from the existence of the unique absolute dimension A to the existence of two dimensions: A, which keeps existing, and $\mathrm{B}$;

2. it is necessary that the two dimensions A and B have a relationship. Moreover, it is necessary that their relationship is the following: the two dimensions $\mathrm{A}$ and $\mathrm{B}$ must be contiguous, but not continuous. That is, A must affirm the existence of B by affirming its radical difference from B (affirming a difference means entailing the existence of an otherness), but must not 
aim at the fusion with B at all. And B must affirm the existence of $A$ by affirming its radical difference from $A$ (affirming a difference means entailing the existence of an otherness), but must not aim at the fusion with $\mathrm{A}$ at all. The relationship between $\mathrm{A}$ and $\mathrm{B}$ must be dualistic.

Thus, the epistemological mechanism which the dualistic relationship between the sacred and the profane seems to entail is characterized as follows: it is necessary that two othernesses (A and B) exist and, moreover, it is necessary for the existence of the former that the content of the latter is divided from the former and it is necessary for the existence of the latter that the content of the former is divided from the latter. The epistemological mechanism is almost paradoxical: both the existence of $\mathrm{A}$ and $\mathrm{B}$ and the relationship between A and B are necessary, but their condition is the rigorous preservation of a dualism, which means a sort of gnoseological mystery, according to which A cannot know what there is precisely in B, since it must not enter $\mathrm{B}$, and $\mathrm{B}$ cannot know what there is precisely in $\mathrm{A}$, since it must not enter $\mathrm{A}$ - the epistemological mechanism which seems to found the dualistic relationship between the sacred and the profane indicates the existence of a relationship which positively works if it is not a matter of fusion, and in particular if it is not a matter of solving a sort of gnoseological mystery.

But what may a dualistic gnoseological relationship which partly denies itself, that is, which is founded on the rigorous preservation of something that must not be known, mean? Let us try to proceed through the analysis of the dualistic relationship between the sacred and the profane. Both Indian culture and, moreover, the Judeo-Christian and the Greek matrixes of Western culture record the necessity of a dualistic gnoseological relationship which partly denies itself. In the Upanishads, for instance, the reference to the sacred is solved by the formula neti, neti ("no, no"), which indicates its unknowableness: the thing that must be known is the irreducible difference between the sacred and the profane, and nothing else. Thus, if a human being knows that the difference between himself and the sacred is irreducible, then he knows all the things he must know about the sacred. On the contrary, if a human being seeks the reduction, that is, the synthesis between himself and the sacred, then he does not know all the things he must know about the sacred, and seeks a reduction and a synthesis which are illusory, and destined not to work at all, and to be even dangerous and consequently banned. The Judeo-Christian matrix of Western culture records an analogous phenomenon. The founding words of Genesis are clearest about the necessity of not knowing ("And the Lord God commanded the man: "You may freely eat of every tree of the garden; 
but of the tree of the knowledge of good and evil you shall not eat, for in the day that you eat of it you shall die" $\left.»^{5}\right)$. And the Greek matrix of Western culture records numerous cases in which the violator of the gnoseological limit is destined to the sparagmos, which means "lacerating, tearing apart, tearing to pieces, tearing off', and is made explicit by Euripides's words about Pentheus. The number of the Greek cases (see, for instance, the destinies of Actaeon, Orpheus and Semele: the first sees Artemis naked and is turned into a deer and torn to pieces by dogs, the second, after having come back from the Hades and failed in saving Eurydice, is torn apart by the Bacchae and the third sees Zeus as a god and dies struck by the lightning) seems to underline the following mechanism: the content of the sacred (the bacchantic feast, Artemis naked, the Hades and Zeus as a god) is, for the human existence, essential and dangerous at the same time - again, the content of the sacred brings salvation and death at the same time, and the reason of its opposite characters seems clearest: knowing the bacchantic feast, Artemis naked, the Hades and Zeus as a god means undermining the necessity of the relationship with the them. That is, if I know the sacred, then my necessity of my relationship with the sacred is undermined, and I start, firstly, to decrease the occasions of relationships between me and the sacred and, secondly, to increase the autonomization of my profane human dimension, and I get to its absolutization - it seems that knowing (too much) means decreasing (too much) the occasions of relationships with something other than oneself and consequently increasing (too much) the danger of autonomization and absolutization of oneself. The direct vision of the bacchantic feast, Artemis naked, the Hades and Zeus as a god means decreasing the necessity of their indirect vision, which is continuous, and not one-time, precisely because of its incompleteness, and, then, it must be iterated in the course of time through an infinite search for occasions of relationships (the human beings' necessity of searching for the sacred is destined to infinitely continue in the course of time if the bacchantic feast keeps being a mystery for Pentheus, Artemis naked keeps being a mystery for Actaeon, the Hades keeps being a mystery for Orpheus and Zeus as a god keeps being a mystery for Semele).

Something important seems to emerge: the essential reason why knowing too much about the sacred (that is, about the otherness par excellence) is banned is the necessity of preserving a gnoseological incompleteness which is the condition of an infinite iteration of the search for occasions of relationships with the sacred (that is, with the otherness par excellence) - it is essential not to know too much about the otherness since

[5] Genesis 2, 16-17. 
what is actually crucial is not discovering a content, but a strategy through which it is possible to infinitely iterate a mechanism of relationship.

Something important seems to emerge also about the epistemological character of the relationship between the sacred and the profane, that is, between two quasi-absolute othernesses: the essence of the phenomenon is epistemological, and does not have to do with a gnoseological completeness - we may argue that the essential thing to be done, and to be guaranteed by a promising strategy, is an act which is epistemological, and does not have to do with a gnoseological completeness: an act through which infinitely searching for and discovering a relationship, and not one-time searching for and discovering a content.

Let us add another element. The authors (philosophers, theologians, anthropologists, sociologists) who study the sacred frequently record the following phenomenon: the sacred is characterized by an irreducible ontological difference from the profane - speaking about the sacred and the profane means speaking about an actual ontological break. Let us order the elements considered, for instance, by Durkheim, Otto and Eliade: the first speaks about an absolute heterogeneity, a separation, abstentions and negative acts ${ }^{6}$, the second speaks about a radical otherness ${ }^{7}$ and the third speaks about an ontological break, splits, fractures, qualitatively different things, a non-homogeneity, an absolute reality and a non-reality ${ }^{8}$. The idea of a radical difference is clear, together with another idea: the radical difference characterizes the almost paradoxical relationship between two othernesses which are said to be absolute, and not mutually relative. Something analogous to the argued quasi-absoluteness seems to happen. That is, A requires B's existence (and consequently A's absoluteness is overcome), but their relationship is sui generis, characterized by abstentions and negative acts which primarily affirm an absolute heterogeneity (and consequently the quasi-absoluteness of A and B is reaffirmed). Thus, the emerging epistemological mechanism seems the following: A affirms the necessity of B's existence not because of the need of being knowable by something else, but because of the need of being unknowable by something else - the emerging epistemological mechanism seems to indicate that, if I have the urgency of affirming A's unknowableness, then the most promising strategy is overcoming A's absoluteness through B's existence, since B, which searches for A's continuously negated knowableness, is the

[6] See É. Durkheim, The elementary forms of religious life, ed. by M.S. Cladis, tr. by C. Cosman, Oxford: Oxford University Press, 2008.

[7] See R. Otto, The idea of the holy. An inquiry into the non-rational factor in the idea of the divine and its relation to the rational, London: Oxford University Press, 1976.

[8] M. Eliade, Patterns in comparative religion, tr. by R. Sheed, New York: New American Library, 1974. 
strategy through which I can most strongly affirm that A is unknowable, and, moreover, must be unknowable.

The structure of the sacrifice is instructive. The etymology of the word "sacrifice" makes reference, again, to something that "makes something sacred" (the Latin adjective sacer, "sacred", joins the Latin verb facere, "to make"). And the etymology dictionary specifies that "sacrifice" means "offering of something (especially a life) to a deity as an act of propitiation or homage" and "act of giving up one thing for another, something given up for the sake of another". Thus, "sacrifice" means "giving up something", that is, deprivation of something, loss of something. Why? That is, why does "making something sacred" means deprivation of something, loss of something? And what is the thing the "sacrifice" forces the deprivation and the loss of? A possible answer is the following: if it is true that "making something sacred" primarily means guaranteeing the absence of a fusion between the sacred and the profane, and in particular of an invasion of the profane into the sacred, then it is also true that "making something sacred" means that the profane is destined to the deprivation and the loss of the possibility of actually entering the sacred - "making something sacred" means causing a deprivation and a loss to the profane, and in particular the paradoxical deprivation and loss of the sacred: the paradoxical meaning of the "sacrifice" is that the condition to which I can "make something sacred" is my deprivation and loss of the sacred.

If we try to transfer the argued mechanism from the sacred to epistemological dynamics, then we have to do with the following structure: the condition of my knowableness of $\mathrm{A}$ is my unknowableness of A. That is, the condition of my knowableness of something about A is my unknowableness of something about A. Let us try to use the words which have to do with the sacred: the condition of my knowableness of something about $\mathrm{A}$ is my sacrifice of my knowableness of something about A. For instance, if my objective is my knowableness of something that has to do with the meaning of my existence (let us say, the answer to the question "Why does the thing B happen to me?"), then the condition to which the answer to the question is possible is my unknowableness of something that has to do with the meaning of my existence (let us say, the ultimate answer to the question "Why does the thing B happen to me?"), since my unknowableness of the ultimate answer to the question is the condition, firstly, of my continuous iteration of the question and, secondly, of my continuous search for the answer, and, at last, of my continuous possibility of finding a present answer which is more promising than the past answer, and a future answer which is more promising than the present answer - the condition of my epistemological relationship with A (of my most promising 
epistemological relationship with A) is my unknowableness of A (my unknowableness of the ultimate answer to the question I ask about A, which, then, I can keep infinitely asking in the future, and keeping infinitely asking means keeping infinitely having a relationship).

Thus, the sacred, together with the dimension of ideality as the dualistic counterpart of the dimension of reality, is the perfect exemplification of the meaning of choosing an epistemological dualism. The reason why choosing an epistemological dualism seems necessary is that it is precisely through the comparison between two radical othernesses that the latter has the greatest possibility of discovering its own identity through its infinite relationship with the former, that is, through the radical distance and unassimilableness which found the infinite relationship of the latter (of the profane, which stands for the reality) with the former (with the sacred, which stands for the ideality). The sacred seems to act as a powerful limit: if I am A, and want to understand who I am, and partly found my future on whom I have understood to be, then the most promising thing I can do is to find the maximum limit from which to understand who I am, since it gives me the possibility of the greatest possible understanding of who I am, that is, of who I am in comparison with all the elements I can both see (for instance, other mortal human beings) and imagine (for instance, immortal gods) - the sacred, together with the ideality, is what, if I am A, then I have not been, I am not and I will not be, since it is my radical otherness, that is, the limit of my ontology from which to get the greatest possible understanding of my ontology.

Thus, the mechanism represented by the bacchantic feast is the perfect exemplification of an epistemological strategy according to which the understanding of any object from the greatest possible distance, that is, from the limit of its existence, is its best condition of cognition - the mechanism represented by the bacchantic feast perfectly exemplifies that what gives us the best way to understand who we are, firstly, and to evolve, secondly, is the epistemological dualism which means irreducible distance and unassimilableness between two othernesses, the former being our reality and the latter being the ideality as our counterpart, which, then, should always be thought of as sacred to us.

\section{References}

Chiodo, S., Apologia del dualismo. Un'indagine sul pensiero occidentale, Roma: Carocci, 2013.

Durkheim, É., The elementary forms of religious life, ed. by M.S. Cladis, tr. by C. Cosman, Oxford: Oxford University Press, 2008. 
Eliade, M., Patterns in comparative religion, tr. by R. Sheed, New York: New American Library, 1974.

Euripides, The Bacchae, tr. by G. Murray, London: Allen, 1906.

Otto, R., The idea of the holy. An inquiry into the non-rational factor in the idea of the divine and its relation to the rational, London: Oxford University Press, 1976. 